\title{
Profil Lemak Darah Pada Ayam Broiler Akibat Ransum Ditambahkan Ekstrak Buah Noni (Morinda citrifolia)
}

\section{Profile of Blood Lipid on Broiler Chicken Due to Dietary of Noni Fruit (Morinda citrifolia) Extract}

\section{Lilik Krismiyanto*, Nyoman Suthama, Bambang Sukamto, Vitus D. Yunianto, Fajar Wahyono dan Istna Mangisah}

Departemen Peternakan, Fakultas Peternakan dan Pertanian

Universitas Diponegoro, Semarang, 50275

\author{
Article history \\ Received: Aug 01, 2020; \\ Accepted: Oct 08, 2020 \\ * Corresponding author: \\ E-mail: \\ lilikkrismiyanto@gmail.com \\ DOI: \\ 10.46549/jipvet.v11i2. 129
}

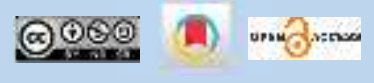

\begin{abstract}
The purpose of the research was to evaluate the effects of feeding noni fruit extract in diet on profile of blood lipid in broiler chicken. A total of 200 unsex broiler chickens weighing $245.67 \pm 10.27 \mathrm{~g}$, noni fruit extract (NFE), ethanol absolute, filter paper, syringe, vacuum tainer, alcohol, and stationery were used in this research. The experiment was assigned in a completely randomized design with 5 treatments and 4 replications (10 birds each). The treatments were: Control $(+)=$ Control Diet $/ C D$, Control $(-)=\mathrm{CD}+$ Bacitracin $0,04 \%, \mathrm{~T} 1=\mathrm{CD}+\mathrm{NFE} 0,04 \%$, $\mathrm{T} 2=\mathrm{CD}+\mathrm{NFE} 0,08 \%$, and $\mathrm{T} 3=\mathrm{CD}+\mathrm{NFE} 0,12 \% \%$. Parameters measured were cholesterol, triglyceride, high density lipoprotein and low density lipoprotein in blood. Data were statistically analyzed using analysis of variance (ANOVA) and the differences $(\mathrm{P}<0.05)$ were determined using Duncan's multiple range test. The results indicated that feeding of NFE significantly effects $(\mathrm{P}<0.05)$ on cholesterol, triglyceride, high density lipoprotein and low density lipoprotein in blood. Feeding of NFE at $0.12 \%$ level (T3) can decrease cholesterol, triglyceride, low density lipoprotein and increase high density lipoprotein in blood compared to other treatments. In conclusion, profile of blood lipid added to NFE until $0,12 \%$ level (T3) indicated a good chicken health, especially on the profile of blood lipid.
\end{abstract}

Keywords: Broiler; Noni fruit extract; Profile of blood lipid

\section{Abstrak}

Penelitian bertujuan untuk mengkaji pengaruh penambahan ekstrak buah Noni (Morinda citrifolia) dalam ransum terhadap profil lemak pada ayam broiler. Sejumlah 200 ekor ayam broiler umur 14 hari dengan bobot badan 245,67 $\pm 10,27$ g. Materi penelitian yang digunakan meliputi eksktrak buah Noni (EBN), ethanol absolute $96 \%$, kertas saring, spuit $5 \mathrm{~mL}$, vacum tainer, alkohol $70 \%$ dan alat tulis. Rancangan penelitian menggunakan rancangan acak lengkap dengan 5 perlakuan dan 4 ulangan (masing-masing diisi 10 ekor). Perlakuan yang diterapkan meliputi Kontrol $(+)=$ Ransum kontrol/RK, Kontrol $(-)=$ RK+Bacitracin $0,04 \%$, T1 $=$ $\mathrm{RK}+\mathrm{EBN} 0,04 \%, \mathrm{~T} 2=\mathrm{RK}+\mathrm{EBN} 0,08 \%$, dan T3= RK+EBN 0,12\%. Parameter yang diukur meliputi kolesterol, trigliserida, high density lipoprotein (HDL) dan low density lipoprotein (LDL) darah. Data dianalisis menggunakan uji Anova dan bila perlakuan menunjukkan pengaruh nyata $(\mathrm{P}<0,05)$ dilanjutkan uji beda nyata Duncan. Hasil penelitian menunjukkan bahwa penambahan EBN berpengaruh $(\mathrm{P}<0,05)$ terhadap kolesterol darah, trigliserida, HDL dan LDL. Penambahan EBN pada level 0,12\% (T3) mampu menurunkan kadar kolesterol, trigliserida dan LDL darah serta meningkatkan HDL darah dibandingkan perlakuan lainnya. Simpulan adalah profil lemak darah yang ditambahkan EBN sampai level 0,12\% (T3) mengindikasikan kondisi kesehatan ayam yang baik, terutama pada lemak darah.

Kata kunci: Ayam broiler; Ekstrak buah noni; Profil lemak darah 


\section{PENDAHULUAN}

Buah mengkudu (Morinda citrifolia) atau dikenal dengan sebutan buah Noni yang umum di masyarakat. Buah Noni banyak ditanam oleh masyarakat di kebun, sebagai pagar hidup dan produksi tanaman herbal. Tanaman Noni dapat tumbuh di dataran rendah dan tinggi pada suhu 22-30 ${ }^{\circ} \mathrm{C}$. Pemanfaatan produk yang dihasilkan dari tanaman buah Noni meliputi daun dan buah. Daun dan buah Noni memiliki manfaat yang sama, jika dilihat dari fungsinya. Fungsi daun dan buah Noni adalah sebagai antibakteri, antiviral, antifungi, antitumor, antihelmik, antiinflamasi, analgesik dan peningkatan imun (Usha et al., 2010). Senyawa aktif yang terdapat pada daun dan buah Noni meliputi polifenol, flavonoid, terpenoid dan tannin. Hasil penelitian Kurniawan (2018) menunjukkan bahwa kadar polifenol ekstrak daun dan buah Noni sebesar $1,095 \mathrm{mg} / \mathrm{g}$ dan $1,67 \mathrm{mg} / \mathrm{g}$ sedangkan kadar antioksidan sebesar $37,54 \%$ dan 84,03\%. Hasil ekstrak buah Noni lebih tinggi dibandingkan daunnya (Kurniawan, 2018). Buah Noni berdasarkan kematangan dapat dibagi 3 yaitu mentah, setengah matang dan matang. Kadar Polifenol pada buah Noni yang mentah, setengah matang dan matang yaitu 2,24; 3,65 dan 6,18\% (Purwantiningsih et al., 2014).

Buah Noni yang digunakan pada penelitian adalah buah yang matang. Buah yang matang dan dilakukan proses ekstraksi untuk mendapatkan senyawa aktif. Karena memiliki kandungan polifenol, flavonoid dan antioksidan yang tinggi. Senyawa yang terkandung dalam ekstrak buah Noni dapat menjadikan alternatif aditif alami yang selama ini sudah dilarang dalam penggunaan antibiotik. Menurut Sinurat et al. (2009) bahwa penggunaan antibiotik secara terus menerus dapat menimbulkan dampak terhadap kesehatan masyarakat, karena adanya residu yang menjadi resisten dalam produk (daging atau telur) serta mengganggu keseimbangan populasi mikroflora dalam saluran pencernaan. Satu bahan alternatif yang dapat menggantikan antibiotik adalah eksktrak buah Noni.
Ekstrak buah Noni ditambahkan dalam ransum ayam broiler digunakan untuk menjaga kesehatan tubuh, terutama pada lemak darah. Kadar lemak ransum pada ayam broiler bervariasi maksimal 8\% (Standar Nasional Indonesia, 2006). Lemak yang tidak terkendali dalam darah mengakibat penurunan lipoprotein. Kolesterol dan trigliserida darah meningkat dapat berdampak terhadap deposisi nutrien dalam jaringan, sehingga produktivitas ayam tidak memenuhi standar (Sumardi et al., 2016). Berdasarkan permasalahan tersebut, penelitian ini bertujuan untuk mengkaji dampak ditambahkan ekstrak buah Noni dalam ransum terhadap kolesterol, trigliserida, high density lipoprotein (HDL) dan low density lipoprotein (LDL) dalam darah.

\section{MATERI DAN METODE}

\section{TERnAK DAN RANSUm PENELITIAN}

Penelitian menggunakan day old chick ayam broiler umur 1 hari dengan rata-rata bobot badan $45 \pm 0,01 \mathrm{~g}$ sebanyak 200 ekor yang dipelihara selama 35 hari. Ransum penelitian disusun dengan protein $21,04 \%$ dan energi metabolis $3.001,96 \mathrm{kkal} / \mathrm{kg}$ dan kandungan nutriennya secara rinci disajikan pada Tabel 1 .

Perlakuan dimulai pada umur 14 hari dengan rata-rata bobot badan 245,67 $\pm 10,27 \mathrm{~g}$ setelah semua ayam beradaptasi dengan ransum kontrol dan kandang battery. Rancangan penelitian disusun menggunakan rancangan acak lengkap dengan 5 perlakuan dan 4 ulangan (masing-masing 10 ekor). Perlakuan yang diterapkan pada penelitian adalah Kontrol $(+)=$ Ransum kontrol/RK, Kontrol (-) = RK+Bacitracin 0,04\%, T1 $=$ RK+EBN 0,04\%, $\mathrm{T} 2=\mathrm{RK}+\mathrm{EBN} 0,08 \%$, dan $\mathrm{T} 3=\mathrm{RK}+\mathrm{EBN}$ $0,12 \%$.

Ekstrak buah noni diberikan setiap pagi hari pukul 07.00 WIB dengan dicampurkan pada ransum sebanyak $20 \mathrm{~g}$, setelah ransum tersebut habis maka ayam diberikan ransum tanpa ekstrak secara ad libitum. Air minum diberikan ad libitum. 
Tabel 1. Ransum penelitian dan kandungan nutrien

\begin{tabular}{|c|c|}
\hline Bahan pakan & Komposisi \\
\hline Jagung Kuning & 44,80 \\
\hline Bekatul & 17,70 \\
\hline Bungkil Kedelai & 26,70 \\
\hline Meat Bone Meal & 9,20 \\
\hline $\mathrm{CaCO}_{3}$ & 0,60 \\
\hline Vitamin dan Mineral & 1,00 \\
\hline Total & 100,00 \\
\hline \multicolumn{2}{|l|}{ Kandungan Nutrien : } \\
\hline Energi Metabolis $(\mathrm{kkal} / \mathrm{kg})^{*}$ & $3.001,96$ \\
\hline Protein Kasar $(\%)^{* *}$ & 21,04 \\
\hline Lemak Kasar $(\%)^{* *}$ & 3,82 \\
\hline Serat Kasar $(\%)^{* *}$ & 5,63 \\
\hline Methionine $(\%) * * *$ & 0,44 \\
\hline Lysine $(\%)^{* * *}$ & 1,33 \\
\hline $\operatorname{Arginin}(\%) * * *$ & 1,49 \\
\hline Kalsium $(\%)^{* *}$ & 1,06 \\
\hline Posphor $(\%)^{* *}$ & 0,66 \\
\hline
\end{tabular}

\section{Keterangan :}

* Berdasarkan perhitungan Bolton (1967).

** Berdasarkan hasil analisis proksimat di Laboratorium Ilmu Nutrisi dan Pakan, Fakultas Peternakan dan Pertanian, Universitas Diponegoro.

*** Berdasarkan Tabel NRC (1994).

\section{PARAMETER PENELITAN}

Data meliputi kolesterol, trigliserida, high density lipoprotein (HDL) dan low density lipoprotein (LDL) dalam darah diukur pada minggu kelima (35 hari). Pengambilan sampel darah melalui pembuluh darah vena sayap (vena brachialis) dari 1 ekor ayam tiap ulangan pada akhir penelitian. Sampel dimasukkan dalam tabung vacuum tainer yang mengandung etilen diamin tetraasetat (EDTA) sebagai antikoagulan, selanjutnya disentrifuse dengan kecepatan $3.000 \mathrm{rpm}$ selama 15 menit. Kolesterol darah dianalisis dengan menggunakan metode enzymatic cholesterol high performance CHOD-PAP KIT.

Trigliserida $(\mathrm{mg} / \mathrm{dl})$ ditentukan dengan menggunakan metode GPO-PAP dengan prosedur sebagai berikut. serum $10 \mu 1$ ditambah $1 \mathrm{ml}$ reagen KIT Trigliserida dan dilakukan penggojokan, kemudian sampel diinkubasi selama 5 menit pada suhu $37^{\circ} \mathrm{C}$ pada inkubator. Selanjutnya sampel diukur dengan spektrofometer pada panjang gelombang 500 nm.
High density lipoprotein diukur menggunakan metode enzymatic cholesterol high performance CHOD-PAP KIT. Plasma sebanyak $20 \mu \mathrm{l}$ ditambahkan reagen KIT Kolesterol-HDL sebanyak $2 \mathrm{ml}$, kemudian digojok dan dimasukkan ke dalam inkubator pada suhu $37^{\circ} \mathrm{C}$ selama 5 menit. Selanjutnya, sampel dilakukan pembacaan pada spektofotometer pada panjang gelombang 500 $\mathrm{nm}$.

Low density lipoprotein diukur menggunakan metode enzymatic cholesterol high performance CHOD-PAP KIT. Plasma sebanyak $10 \mu \mathrm{l}$ ditambahkan $1 \mathrm{ml}$ reagen KIT Kolesterol, kemudian digojok dan dimasukkan ke dalam sentrifuge dengan kecepatan 2.500 rpm selama 10 menit. Selanjutnya, sampel ditambahkan $1 \mathrm{ml}$ KIT LDL dan dilakukan penggojokan. Sampel dimasukkan incubator pada suhu $37^{\circ} \mathrm{C}$ selama 5 menit. Lalu, sampel dilakukan pembacaan pada spektofotometer pada panjang gelombang $500 \mathrm{~nm}$.

\section{RANCANGAN PERCOBAAN}

Penelitian menggunakan rancangan acak lengkap dengan 5 perlakuan dan 4 ulangan 
(masing-masing 10 ekor). Perlakuan yang diterapkan pada penelitian sebagai berikut:

Kontrol $(+)=$ ransum kontrol/RK

Kontrol $(-)=$ RK + bacitrasin $0,04 \%$

$\mathrm{T} 1=\mathrm{RK}+$ ekstrak buah Noni $0,04 \%$

$\mathrm{T} 2=\mathrm{RK}+$ ekstrak buah Noni $0,08 \%$

$\mathrm{T} 3=\mathrm{RK}+$ ekstrak buah Noni $0,12 \%$

Data yang diperoleh diolah dengan analisis ragam pada taraf 5\% untuk mengetahui pengaruh perlakuan terhadap peubah yang diukur. Apabila berpengaruh nyata dilanjutkan dengan uji Duncan pada taraf 5\% (Gaspersz, 1991).

\section{HASIL DAN PEMBAHASAN}

Hasil penelitian dengan penambahan ekstrak buah Noni (EBN) dalam ransum ayam broiler berpengaruh nyata $(\mathrm{P}<0,05)$ terhadap profil lemak darah (kolesterol, trigliserida, HDL dan LDL). Hasil profil lemak darah dapat disajikan pada Tabel 2.

Penambahan EBN dalam ransum berpengarh nyata $(\mathrm{P}<0,05)$ menurunkan kadar kolesterol dalam darah. Jika dilihat pada penambahan EBN 0,12\% (T3) sebesar 101,35

Tabel 2. Profil lemak darah ayam broiler
mg/dL dapat menurunkan kadar kolesterol darah dibandingkan perlakuan lainnya (kontrol (+) $138,9 \mathrm{mg} / \mathrm{dL}$, kontrol (-) 138,24 mg/dL, T1 $127,86 \mathrm{mg} / \mathrm{dL}$ dan T2 124,83 mg/dL). Ekstrak buah Noni memiliki senyawa aktif yaitu antioksidan seperti polifenol dan flavonoid. Berdasarkan hasil analisis di Laboratorium Ilmu Nutrisi dan Pakan (2020) bahwa kadar polifenol sebesar $1,2 \%$ dan flavonoid sebesar $3,17 \%$. Senyawa aktif ini pada saat di dalam saluran pencernaan menghambat penyerapan kolesterol. Kolesterol akan membentuk senyawa komplek dan keluar bersama ekskreta. Menurut Sunarno dan Djaelani (2018) bahwa polifenol berkerja untuk meregulasi penyerapan lemak atau kolesterol oleh sel epitelus usus. Artha et al. (2017) menyatakan bahwa flavonoid beperan sebagai inhibitor enzim HMG-CoA reduktasi, sehingga sintesis kolesterol mengalami penurunan. Kolesterol pada saat ditranspor dari usus ke hati, maka HMG-CoA yang berperan mengubah asetilkoA menjadi mevalonat dalam menghambat sintesis kolesterol, sehingga produk yang dibawa ke hati menjadi berkurang.

\begin{tabular}{|c|c|c|c|c|c|}
\hline \multirow{2}{*}{ Parameter } & \multicolumn{5}{|c|}{ Perlakuan } \\
\hline & $(+)$ & $(-)$ & T1 & $\mathbf{T 2}$ & T3 \\
\hline & $-\cdots$ & -------- & ng/dl------ & --------- & ------ \\
\hline Kolesterol & $138,90^{\mathrm{a}}$ & $138,24^{\mathrm{a}}$ & $127,86^{\mathrm{a}}$ & $124,83^{\mathrm{a}}$ & $101,35^{\mathrm{b}}$ \\
\hline Trigliserida & $209,65^{a}$ & $198,66^{\mathrm{a}}$ & $151,83^{b}$ & $151,55^{b}$ & $114,20^{c}$ \\
\hline HDL & $63,75^{\mathrm{b}}$ & $69,00^{\mathrm{ab}}$ & $74,75^{\mathrm{ab}}$ & $72,7^{\mathrm{ab}}$ & $79,75^{\mathrm{a}}$ \\
\hline LDL & $65,55^{\mathrm{a}}$ & $62,07^{\mathrm{a}}$ & $51,35^{\mathrm{b}}$ & $50,83^{b}$ & $37,61^{\mathrm{c}}$ \\
\hline
\end{tabular}

abc Superskip yang berbeda pada baris yang sama menunjukkan perbedaan nyata $(\mathrm{p}<0,05)$.

Kontrol (+)=ransum control/RK; Kontrol (-)=RK+Bacitrasin 0,04\%; T1=RK+EBN 0,04\%; T2=RK+EBN $0,08 \%$ dan $\mathrm{T} 3=\mathrm{RK}+\mathrm{EBN} 0,12 \%$.

Penambahan EBN $0,12 \% \quad(\mathrm{~T} 3)$ berpengaruh nyata $(\mathrm{P}<0,05)$ menurunkan trigliserida dibandingkan perlakuan lainnya (Kontrol (+), (-), T1 dan T2). Jika dilihat pada penambahan EBN dapat menurunkan trigliserida darah dibandingkan ransum kontrol (+) $209.65 \mathrm{mg} / \mathrm{dL}$ dan ransum dengan bacitrasin (-) 198,66 mg/dL. Level EBN yang paling tinggi $(0,12 \%)$ sejalan dengan kolesterol darah yang dapat menurunkan trigliserida darah. Kolesterol dan trigliserida merupakan bagian lemak yang digunakan untuk mendeteksi tubuh. Penurunan trigliserida diakibatkan adanya polifenol dan flavonoid yang menghambat kerja lipase, sehingga lemak yang diserap menjadi berkurang (Budiarto et al., 2016). Menurut Ariviani (2010) bahwa penurunan kolesterol dan trigliserida adanya konsekuensi dari penurunan glukosa darah dan asetil Co-A yang masuk ke dalam siklus Krebs, sehingga ketersediaannya untuk disintesis menjadi terbatas. Sebaliknya, pada ransum kontrol (+) dan (-) menunjukkan kadar trigliserida yang tinggi diakibatkan kerja bacitracin yang berperan sebagai antibakteri, sehingga tidak dapat menghambat kerja lipase 
dan penyerapan lemak. Rizki et al. (2015) menyatakan bahwa penumpukkan lemak dalam jaringan dan aktivitas lipase yang rendah diakibatkan radikal bebas yang mengganggu hidrolisis trigliserida, sehingga kadar trigliserida menjadi tinggi. Menurut Sulistyoningsih (2014) bahwa antioksidan dapat meningkatkan sekresi garam-garam empedu yang berperan dalam proses biosintesis akibatnya terjadi peningkatan metabolisme lemak dengan hasil akhirnya adenosine trifosfat (ATP), ATP hasil metabolisme lemak digunakan untuk metabolisme asam amino sehingga penimbunan lemak dalam tubuh menjadi rendah.

Hasil penelitian pada HDL akibat ditambahkan EBN 0,12\% (T3) berpengaruh nyata $(\mathrm{P}<0,05)$ lebih tinggi dibandingkan ransum kontrol (+), tetapi $\mathrm{T} 3$ memiliki pengaruh yang sama dengan perlakuan T1, T2 dan ransum kontrol ditambahkan bacitrasin (-). Penambahan EBN level tertinggi 0,12\% (T3) dapat meningkatkan HDL diakibatkan senyawa aktif (polifenol dan flavonoid) yang terkandung di dalam ekstrak Noni mampu menghambat kerja lipase dan penyerapan lemak. Menurut Tugiyanti et al. (2016) bahwa polifenol dan antioksidan memutus reaksi pembentukan kolesterol di usus dengan menginaktifkan enzim HMG-CoA reduktase dan meningkatkan ekskresi garam empedu. Hasanuddin et al. (2013) menyatakan bahwa tinggi rendahnya kadar HDL dalam darah berkorelasi dengan kadar kolesterol. Hasil penelitian ini menunjukkan bahwa kadar HDL berkorelasi dengan kolesterol, dimana pada level ekstrak tertinggi $(0,12 \%)$ mampu menurunkan kolesterol darah dan meningkatkan HDL.

Hasil uji Duncan pada taraf 5\% menunjukkan bahwa penambahan EBN 0,12\% (T3) berpengaruh nyata $(\mathrm{P}<0,05)$ menurunkan LDL dalam darah. Kadar LDL sangat berkorelasi dengan HDL, dimana penambahan EBN 0,12\% (T3) dapat meningkatkan HDL dalam darah. Tingginya LDL juga berkorelasi dengan kadar kolesterol (T3). Tugiyanti et al. (2016) menyatakan bahwa sintesis kolesterol di dalam hati berdampak pembongkaran cadangan lemak di dalam sel adipose, laju HDL meningkat menuju hati membawa asam lemak hasil katabolisme untuk disintesis menjadi kolesterol. Senyawa antioksidan dapat menurunkan LDL dan meningkatkan HDL, karena senyawa tersebut mendonorkan hydrogen pada radikal peroksil. Yadnya et al. (2017) menyatakan bahwa senyawa antioksidan dapat menghambat aktivitas kerja enzim 3 hidroksi, metyl-gluteryl-Ko-A, sehingga berubah dari asam mevalonat menjadi 3 hidroksi, 3 metyl, gluteryl-Ko-A berkurang produksinya dan kolesterol yang terbentuk dalam jaringan atau hati berkurang.

\section{KESIMPULAN}

Berdasarkan hasil penelitian dapat disimpulkan bahwa profil lemak darah yang ditambahkan EBN sampai level 0,12\% (T3) mengindikasikan kondisi kesehatan ayam yang baik, terutama pada lemak darah.

\section{DAFTAR PUSTAKA}

Ariviani S. 2010. Pengaruh diet ekstrak buah salam (Syzygium polyanthumr [Wight] Walp) terhadap kadar glukosa darah dan profil lipid (total kolesterol, HDL-C, LDL$\mathrm{C}$ dan trigliserida) pada tikus wistar. Jurnal Teknologi Hasil Pertanian. 3(1): 21-27. DOI:

https://doi.org/10.20961/jthp.v0i0.13616.

Artha C, Mustika A dan Sulistyawati SW. 2017.

Pengaruh ekstrak daun singawalang terhadap kadar LDL tikus putih jantan hiperkolesterolemia. Jurnal Kedokteran Indonesia. 5(2): 105-109. DOI: 10.23886/ejki.5.7151.

Budiarto MA, Yuniwarti EYW dan Isroli. 2016. Pengaruh pemberian tepung daun jati belanda (Guazuma ulmifolia L.) dalam pakan terhadap kadar trigliserida darah dan lemak abdominal ayam broiler. Bulletin Anatomi dan Fisiologi. 1(1): 4347.

DOI: https://doi.org/10.14710/baf.1.1.2016.4347

Bolton W. 1967. Poultry Nutrition. MAFF Bulletin. No.174. HMSO, London.

Gaspersz V. 1991. Teknik Analisis dalam Penelitian Percobaan. Tarsito. Bandung.

Hasanuddin S, Yunianto VD dan Tristiarti. 2013. Profil lemak darah pada ayam broiler yang diberi pakan step down protein 
dengan penambahan air perasan jeruk nipis sebagai acidifier. Jurnal Ilmu dan Teknologi Peternakan. 3(1): 11-17.

Kurniawan D. 2018. Aktivitas antimikroba dan antioksidan esktrak tepung dan buah mengkudu (Morinda citrifolia). Jurnal Ilmu-Ilmu Peternakan. 28(2):105-111. DOI:

https://doi.org/10.21776/ub.jiip.2018.028. 02.02 .

National Research Council. 1994. Nutrient Requirement of Poultry. 9th Rev. Ed. National Academic Press Washington, D. C. 9th Revised Ed.

Purwantiningsih TI, Suranindyah YY dan Widodo. 2014. Aktivitas senyawa fenol dalam buah mengkudu (Morinda citrifolia) sebagai antibakteri alami untuk penghambatan bakteri penyebab mastitis. Buletin Peternakan. 38(1): 59-64. DOI: https://doi.org/10.21059/buletinpeternak.v $38 \mathrm{i} 1.4618$.

Rizki PR, Jayanti RD dan Widyanignsih TD. 2015. Pengaruh teh berbasis daun cincau hijau (Premna oblongifolia Merr.) terhadap glukosa darah dan profil lipid tikus hiperglikemia. Jurnal Pangan dan Agroindustri. 3(3): 803-8014. https://jpa.ub.ac.id/index.php/jpa/article/vi ew/202

Sinurat AP, Purwadaria T, Bintang IAK, Ketaren PP, Bermawie N, Rahardjo M dan Rizal M. 2009. Pemanfaatan kunyit dan temulawak sebagai imbuhan pakan untuk ayam broiler. JITV. 14(2):90-96. DOI: https://dx.doi.org/10.14334/jitv.v14i2.349

Standar Nasional Indonesia. 2006. Pakan Ayam Ras Pedaging (SNI 01-3931-2006). Badan Standar Nasional, Jakarta.

Sulistyoningsih M. 2014. Optimalisasi produksi broiler melalui suplementasi herbal terhadap persentase karkas dan kadar trigliserida darah. Bioma. 3(1):7893. DOI: https://doi.org/10.26877/bioma.v3i1,\%20 April.652.

Sumardi, Sutyarso, Susanto GN, Kurtini T, Hartono M dan Rr Etty PNW. 2016. Pengaruh probiotik terhadap kolesterol darah pada ayam petelur (layer). Jurnal Kedokteran Hewan. 10(2):128-131. DOI: https://doi.org/10.21157/j.ked.hewan.v10i 2.5042

Sunarno dan Djaelani MA. 2018. Suplementasi tepung kulit kayu manis dan daun pegagan dalam pakan terhadap kandungan kolesterol dan antioksidan telur puyuh (Cortunix cortunix australica). Bioma. 7(1):65-81.

DOI: https://doi.org/10.26877/bioma.v7i1.2539. Tugiyanti E, Heriyanto S dan Syamsi AN. 2016. Pengaruh tepung daun sirsak terhadap karakteristik lemak darah dan daging itik tegal jantan. Buletin Peternakan. 40(3):211-218. DOI: https://doi.org/10.21059/buletinpeternak.v 40i3.11243.

Usha R, Sangeetha S and Palaniswamy P. 2010. Antimicrobial activity of rarely known species, Morinda citrifolia, $L$. Ethnobotanical. Ethnobotanical Leaflets. 14: 306-311. DOI: https://opensiuc.lib.siu.edu/ebl/vol2010/is s3/7.

Yadnya TGB, Wirawan IW, Wibawa AAPP dan Sukmawati NMS. 2017. Upaya perbaikan nutrisi dan profil lipida telur pada itik bali yang mendapatkan sekam padi mengandung daun noni (Morinda citrifolia) disuplementasi multienzim. Majalah Ilmiah Peternakan. 20(2):49-54. DOI: https://doi.org/10.24843/MIP.2017.v20.i0 2.p02. 